\title{
Learning from experience - a probe into the off-campus internships under the five-year cosmetology technical and vocational education program
}

Internship under five-year cosmetology

program

\author{
Yeh Ju-Hsuan
}

Department of Cosmetic Applications and Management, Cardinal Tien Junior College of Healthcare and Management, New Taipei, Taiwan and

The Graduate Institute of Design Science, Tatung University, Taipei, Taiwan

Tsai-Yun Lo

Department of Industrial Design, Tatung University, Taipei, Taiwan

Ming-Chang $\mathrm{Wu}$

Graduate School of Technological and Vocational Education, National Yunlin University of Science and Technology, Yunlin, Taiwan, and Li-Feng Wang Department of Film and Television, Lee-Ming Institute of Technology, New Taipei, Taiwan

\begin{abstract}
Purpose - This paper aims to probe into the implementation of internship courses under the five-year cosmetology program in Taiwan from the perspective of Dewey's philosophies in hopes that the analysis can serve as reference for schools in planning their internship courses in the future.

Design/methodology/approach - This paper probes into the off-campus internship courses under Taiwan's five-year junior college education program by applying Dewey's empirical philosophy.

Findings - The study aims to understand the learning experience acquired by students from learning by doing internship courses as reference for future internship design. The current internship courses comprise the follows: summer, during the semester and for a full academic year. The experience of summer internship is career exploration, the experience for semester internship is career experience and the experience from academic-year internship is career choice. The internship strategies are designed according to the three different internship approaches, so that the internship courses can implement the educational effect of "learning from experience".

Practical implications - To minimize the discrepancy between the cosmetology program under the fiveyear junior college education and the employment market, credit-based off-campus internship courses are arranged for students' final years at school.

Social implications - Through on-site trainings, students accumulate work experience and explore into a related career field. The accumulation of experience and gaining of insights mirror the philosophy of learning by doing, which involves students' reflective thinking.
\end{abstract}

(C) Yeh Ju-Hsuan, Tsai-Yun Lo, Ming-Chang Wu and Li-Feng Wang. Published by Emerald Publishing Limited. This article is published under the Creative Commons Attribution (CC BY 4.0) licence. Anyone may reproduce, distribute, translate and create derivative works of this article (for both commercial \& non-commercial purposes), subject to full attribution to the original publication and authors. The full terms of this licence may be seen at http://creativecommons.org/licences/by/4.0/legalcode

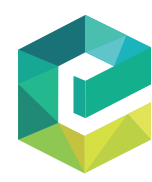

Received 14 March 2019

Revised 7 August 2019 2 April 2020

Accepted 8 April 2020

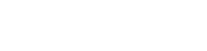


HESWBL 11,2
Originality/value - It is hoped that the analysis can serve as reference for internship courses planning in the future.

Keywords Five-year junior college programs, Cosmetology technical and vocational education, Off-campus internship, Experience, Learning by doing

Paper type Research paper

\section{8}

\section{Introduction}

In recent years, changes in the economic pattern have brought prosperity in the "beauty economy," as well as expansion of the beauty-related industries. These industries build on techniques, products and services such as cosmetics formulation, cosmetics counter sales, aromatherapy, medical beauty, hair styling, nail and eyelash arts and wedding styling. Given the current trend, growth is rapid for local cosmetics manufacturers. The number of factories increased from 582 in 2007 to 753 in 2015, rising by an average of 3.4\% per year. Meanwhile, the number of employees also increased at a rate of $6.5 \%$ annually, from 8,000 in 2007 to 14,000 in 2015. In 2017, the cosmetics exports reached US\$730 $\mathrm{m}$, with an annual growth rate of $13.2 \%$ (Ministry of Economics, 2018). On Taiwan's two major job search websites, it is shown that on December 8,2018, there were 1,969 beauty jobs available, 1,311 makeup artist jobs, 809 spa jobs (1111 Job Bank, 2018), another 5,610 beauty jobs, 1,527 hairdressing jobs and 310 stylist jobs (104 Job Bank, 2018). The release of multiple job vacancies for only one day suggests the urgent demand of beauty-related industries for more manpower.

Currently, the beauty-related industries are shifting the business model to sophisticated trends in order to take up more market share, which suggests the demand for middle-level manpower to enter the workplace. $\mathrm{Hu}$ (2013) points out that middle-level technical manpower comprises the majority of the labor market and is trained under the five-year junior college education program. The five-year junior college education refers to the teaching of applied sciences and technology to cultivate talents with professional and practical skills. With a duration of five years, the program provides linking after junior high school education, and a total of no less than 220 credits are required to complete the program (Ministry of Education, 2014). The cosmetology technical and vocational education program is one of the tracks under the five-year junior college program. It is asserted by Moodie (2002) that the purpose of vocational education is to prepare students for the job market with up-to-date professional knowledge, ranging from basic skills, problem-solving skills, to appropriate work attitudes and employability skills, technical skills and other vocational skills. Regarding the course content of the vocational education program, King (1993) argues that it should be "basicability-training"-oriented, with an emphasis on the knowledge and skills especially needed in the workplace. Therefore, the curriculum design of the vocational education program should be compatible with the employment environment.

The five-year cosmetology technical and vocational education program offers both theoretical knowledge and practical skill trainings, and this type of education is inspired by Dewey. As a 20th-century American pragmatist philosopher, thinker and educator, Dewey suggests that educational activities be based on students' life experience and that from experience they learn and gain more experience. For example, through being hands-on in activities, students will gain professional knowledge and skills encompassing cosmetic technology, makeup artistry, overall styling and health services provided for potential clients. Students will also accumulate pleasant memories and eventually learn to appreciate the intrinsic value of various disciplines. In conformation with Dewey's educational belief that students should receive education from which they can extract both intrinsic and practical values, the curriculum objectives should be to equip students with skills in line with the world of work; in addition, students can find a variety of course options that take their personal traits, personal interests and expertise into consideration. In so doing, it is easier for 
students to be recruited upon graduation, without incurring excessive costs, letting resources go to waste or having to address the skill mismatch problem (Billett et al., 2010). Founded on this belief, the current internship courses under the five-year vocational education program serve the same purposes.

As of now, 16 schools in Taiwan have arranged for students to take off-campus internships courses under their five-year cosmetology program. The off-campus internship courses are scheduled for the fourth and fifth years of the five-year studies, with three different types of internships available, namely summer internships, internships during the semester and internships for a full academic year. Nonetheless, the internship courses executed by school differ while enterprises vary in remuneration paid to students during internships. Moreover, students have different career plans and interests for the internships. For a proper arrangement of the internship courses that take into account the needs of the students, schools and enterprises, issues about internship courses warrant attention in the field of vocational education. In view of this, and with the author's experience of teaching in this field and 10-year involvement in the off-campus internship education, this paper aims to probe into the implementation of internship courses under the five-year cosmetology program in Taiwan from the perspective of Dewey's philosophies in hopes that the analysis can serve as reference for schools in planning their internship courses in the future.

\section{Educational significance of learning from experience}

\subsection{Educational significance of experience reflective under the interaction effect of} consecutive activities and ensuing consequences

The concept of "to learn from experience," or "learning by doing," is put forward by Dewey, American philosopher, proponent of pragmatism and representative figure of progressivism. Education is the reconstruction and transformation of experience, and experience is the foundation for learning $(\mathrm{Wu}, 2009)$. Dewey mentions that the three contributing factors of experience reconstruction and transformation are "organism," "environment" and the interaction of the two, all of which also have an impact on the shaping of personal experiences. It is noted that the scope of experience can be quite extensive, encompassing a variety of aspects from life experiences, what one sees and hears, to sentiment and cognitive thinking (Lin, 2007). The experience referred to in this paper is experience pertaining to the cosmetics internship courses, which involves the employers, colleagues and clients, as well as their activities or interactions in the workplace and the ensuing consequences.

Experience is two sides of the same coin. Dewey (1944) views experience as the peculiar combination of the positive and negative sides of itself. The positive experience is an experiment carried out by students after their active and conscious thinking, whereas negative experience is an encounter in which students suffer from and take responsibilities for the consequences after their activities in the positive experience. Experience can be described as having two sides. On the one hand, people actively try and act; on the other hand, people passively go through an incident by accepting and enduring the consequences. Each activity an individual undertakes comes along with an inevitable consequence, and thus experience is a cyclic progress of activities and consequences.

Dewey points out that "the method of trial and error" in the field of psychology does not account for the otherwise meaningful connections between an individual's activities and the consequences, for a failed attempt is in its essence accidental and coincidental. Thus, a systematic and structural method has yet to be employed. Dewey suggests the meaning lies in "reflection in experience." The reason why the connections are established from people's activities and the consequences is that thought is an integral, yet unseen part of experience. With thought, the experience becomes a type of "experience reflective" or "reflective par excellence" and begins to carry a deep meaning (Wu, 2009).
Internship under five-year cosmetology program

589 
HESWBL 11,2

2.2 The learning stages from the accumulation of "experience," the formation of "concepts," to the development of "knowledge"

In the book How We Think, Dewey explains that nothing in education is more important than the stage of concept formation. He also emphasizes that each experience has its educational value and that concepts are formed and transformed from an individual's experience, reflection and activities (Gordon and English, 2016). Being exposed to the outer world, an individual sees with the mind's eye and learns through their senses. Following a thorough understanding and sound judgment, a complete "concept" starts to form. Through the combination of a large number of "concepts," concrete "knowledge" is then developed. The influence of an individual's experience is best described with the Western proverb that goes "one ounce of experience is better than a ton of theory" (Lin, 2012).

Dewey believes that knowledge should be actively generated by an individual. Someone knowledgeable engages himself or herself in the exploration into his or her life experience, and the construction of knowledge from this exploration never ceases for him or her, as Dewey (1944:86) points out in the book Democracy and Education that "[if] the living, experiencing being is an intimate participant in the activities of the world to which it belongs, then knowledge is a mode of participation, valuable in the degree to which it is effective. It cannot be the idle view of an unconcerned spectator" (Attick, 2007). From the perspective of labor technicians, Billett (2001a, 2001b) argues that the work environment is the only place for them to improve knowledge and skills in their career field and that to achieve a better job performance, they must always seek excellence and self-improvement to the level of forming new concepts and add the concepts into their repertoire of knowledge.

The students enrolled in the five-year cosmetology program are taught a series of professional skills and knowledge in the workplace. The integration of on-site trainings enables students to draw upon a wide range of skills needed in the workplace through the process of "concept formation" and integration to yield "knowledge" about beauty-related jobs. For example, the knowledge of "nail extensions" application as practiced in the nail salon industry is acquired through an integration of such concepts as the shapes of the nails, the nail glue, nail molds and nail files. Among these concepts, different types of nail files can be further classified based on the thickness of the files, as well as the force, direction, angle and velocity of the produced friction. Therefore, the acquisition of workplace experience is the accumulation of experience, organization of vocational skill-related concepts and the internalization into an individual's professional knowledge.

\section{Overview of the off-campus internships under the five-year cosmetology vocational education}

3.1 Current situations of internships under the five-year cosmetology programs in Taiwan

The five-year junior college program is one of the options for students to pursue further studies after junior high school graduation. The students are aged 16-20 and required to earn at least 220 credits. They are awarded an associate degree upon completion of the program. Judging from relevant information about the course structure of the five-year college cosmetology programs, it is found that (1) courses available in the departments under the healthcare sector focus on makeup artistry and health care; (2) courses available at general universities or universities of science and technology focus on fashion styling. Regardless of which systems the departments belong to, off-campus internship courses are included in the curriculum for both systems.

For the concept on off-campus internship courses, refer to the advantage of "Sandwich course." Students acquire theoretical knowledge and professional ethics in school and later engage in technical internship in enterprises. However, the real implementation is taken from the internship model from the University of Cincinnati in 1906, where students expand learning outside of the class and enhancing their workplace experience in relevant industries. 
Students will boost their employment competency in future workplace while the cooperation between schools and industries provides the place for students to dedicate efforts in internship while the industries pay students salary in return (Chang and Wong, 2016). The off-campus internship courses under the five-year cosmetology program allow students to adopt a learning-by-doing approach and do an experiential learning in the workplace. Apart from learning in the workplace, they still return to school on a regular basis to attend classes, workshops and seminars, so as to balance school education and the internship training. Currently, there are three types of internship courses available under the five-year cosmetology programs (see Figure 1), including summer courses (2 credits or more, 8 consecutive weeks/at least $320 \mathrm{~h}$ ), semester courses (9 credits or more, at least 4-5 months), academic year course (18 credits or more, at least 9 months) (Ministry of Education, 2016). Interns are required to regularly return to school as stipulated in the curriculum plan of their department. For the majority of the schools, the interns are asked to spend one day at school per week so as to keep on learning both at the internship site and at school

3.1.1 Summer course. Currently there are two schools adopting "summer courses" for the second semester of the fourth year. After the students have acquired basic technical knowledge and skills from school education, they will intern at the industries for merely two months but will leave the internship companies to return to school after familiarizing with the work for some time. Students can still meet the value of career exploration through summer internships even if their access to the industries is only a short period of time

3.1.2 Courses for a full academic year. Seven schools had adopted the "courses for a full academic year," which is applicable to the course design for counseling students in employment orientation with longer period of internship hours. Students will be competent for the entry-level employee duties at the courses for a full academic year; corporate employers prefer the learning approach of courses for a full academic year while willing to pay full salary to interns. Based on the viewpoints of talent fostering, some large companies have signed "Industry-College Cooperation Program" with schools to protect students with employment upon graduation. Apart from paying for reasonable salary, those companies also pay for the students' tuition during school enrollment

3.1.3 Semester courses. Eight five-year cosmetology technical and vocational schools adopt "semester courses" and the majority of schools are inclined to design the internship course via semester course. For a small portion of schools, internship courses are arranged for the spring semester of the fifth year as an elective course often titled "advanced internship -fall semester" so that students are still provided with both professional and general courses

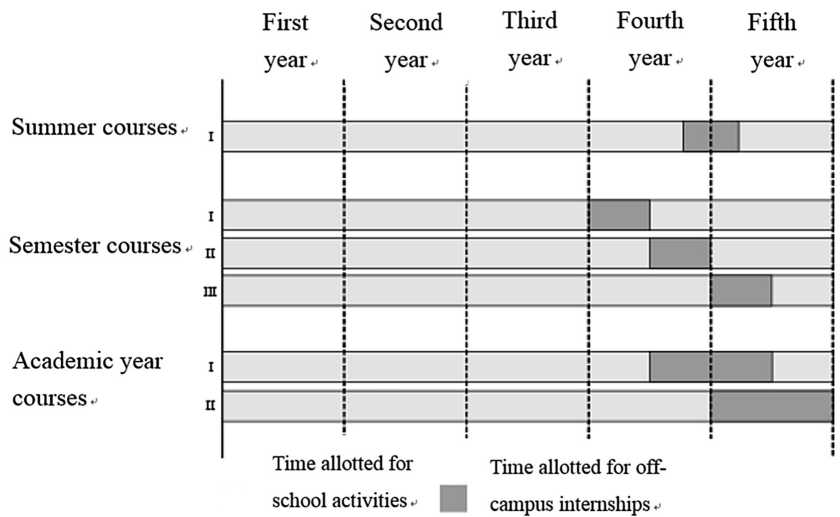

Internship under five-year cosmetology program
Figure 1.

Curriculum planning of the internship courses under the five-year cosmetology programs 
HESWBL 11,2

\section{2}

in the fifth year of their studies and allow students adequate time to ponder and think about their career plans.

\subsection{Content of the internships in the beauty-related industries}

According to Ministry of Education (2017), a total of 16 five-year college cosmetology programs are open for applications, and the programs are named in tune with the current trend toward a diversified development in the beauty-related industries. The industries under discussion can be classified into five main areas, namely the makeup artistry, beauty styling, health care, pet grooming and beauty tourism. The compilations of enterprises offering internship to the five-year cosmetology education programs in Taiwan reflect the course structure of five-year cosmetology education. The internship companies for most departments offer: basic sales and management-related work, makeup artistry, beauty styling, cosmetology care and beauty tourism, all of which offer internship units for manicure, pedicure and skincare massage. The department collaborating with internship for hair salon and wedding photography features cosmetics, beauty styling and cosmetology care. Other specific industries: pet grooming stores and veterinary clinic consist of pet grooming department while internship units for leisure farm and resorts target at the department of beauty tourism. There is some discretion in the properties of development for the corresponding departments of internship companies, overview of which between the department and internship companies is presented as follows (Table 1).

\subsection{Relationship between the internship courses and relevant industries for the five-year cosmetology education program in Taiwan}

The study compiled data analysis on the internship courses of each school and conducted focus group interview with five teachers from relevant departments and five employees from relevant industries, thereby probing into the relationship of internship courses between the relevant departments and industries of five-year cosmetology education program.

\begin{tabular}{|c|c|c|}
\hline $\begin{array}{l}\text { Attributes of the } \\
\text { department }\end{array}$ & Enterprises looking for interns & Internship job descriptions \\
\hline $\begin{array}{l}\text { Makeup } \\
\text { products }\end{array}$ & $\begin{array}{l}\text { Biotechnological companies specializing in } \\
\text { makeup products, hairdressing salons, } \\
\text { wedding photography, manicure and } \\
\text { pedicure, skincare and massage and counter } \\
\text { sales }\end{array}$ & $\begin{array}{l}\text { Makeup products packaging and } \\
\text { ingredient management, makeup sampling } \\
\text { assistants, honor attendants, wedding } \\
\text { outing assistants, manicurists, aroma } \\
\text { therapists and counter sales } \\
\text { representatives of makeup brands }\end{array}$ \\
\hline Beauty styling & $\begin{array}{l}\text { Television production companies, } \\
\text { hairdressing salons, wedding photography, } \\
\text { manicure and pedicure, skincare and } \\
\text { massage and counter sales }\end{array}$ & $\begin{array}{l}\text { Television makeup artists, hairdressing } \\
\text { assistants, wedding secretaries, wedding } \\
\text { outing assistants, manicurists, aroma } \\
\text { therapists and counter sales } \\
\text { representatives of makeup brands }\end{array}$ \\
\hline Health care & $\begin{array}{l}\text { Hairdressing salons, wedding photography, } \\
\text { manicure and pedicure, skincare and } \\
\text { massage, counter sales }\end{array}$ & $\begin{array}{l}\text { Hairdressing assistants, wedding } \\
\text { secretaries, wedding outing assistants, } \\
\text { manicurists, aroma therapists and counter } \\
\text { sales representatives of makeup brands }\end{array}$ \\
\hline Pet grooming & $\begin{array}{l}\text { Pet salons, veterinary clinics and counter } \\
\text { sales }\end{array}$ & $\begin{array}{l}\text { Pet grooming assistants, veterinary } \\
\text { assistants, pet products retail sales } \\
\text { representatives and pet training assistants }\end{array}$ \\
\hline $\begin{array}{l}\text { Health and } \\
\text { beauty tourism }\end{array}$ & $\begin{array}{l}\text { Recreational farms and resorts, manicure } \\
\text { and pedicure, travel agencies, skincare and } \\
\text { massage, hospitality management, } \\
\text { hospitality and tourism }\end{array}$ & $\begin{array}{l}\text { Aroma therapists, travel assistants, staff } \\
\text { members in the tourism industry, } \\
\text { assistants at MICE consulting firms, } \\
\text { tourist leaders or assistant tour guides }\end{array}$ \\
\hline
\end{tabular}

Makeup products packaging and ingredient management, makeup sampling assistants, honor attendants, wedding representatives of makeup brands Television makeup artists, hairdressing assistants, wedding secretaries, wedding representatives of makeup brands Hairdressing assistants, wedding manicurists, aroma therapists and counter sales representatives of makeup brands Pet grooming assistants, veterinary representatives and pet training assistants Aroma therapists, travel assistants, staff assistants at MICE consulting firms, tourist leaders or assistant tour guides therapists and counter sales

\section{Table 1.}

Overview of the offcampus internship courses under the fiveyear cosmetology programs 
The data in Table 2 reveal the relevance between internship courses and content of industry works. Among which, "internship during the semester" courses account for the majority, while all five-year cosmetology education program related departments arrange for "internship during the semester" courses. Some schools arrange for two internships during the semester, so that the semester-based internship courses can be incorporated in the fourth and fifth year. The main purpose aims at students who already received influence of advanced knowledge and skills provided by school education to acquire the relevant professional certificates. The purpose of internship during the semester intends to help students experience the work at workplace through the weekly return to school for class or participation in seminars. Students intern at the industries during other times to maintain consistency between the knowledge and skills from the industry and schools. Students will develop competency for the middle-level assistant jobs in enterprise. For example, cosmetics package and product management, intermediate-level assistant in hair salon industry (hair conditioning, hair drying and styling), manicure assistance (basic maintenance, nail painting), aroma therapy massage assistant, pet groomer's assistant (assisting with pet cleaning, maintaining and nail clipping), vet assistant (assisting with clinic registration, product management and sales and in-hospital animal medicinal administration and food feeding), salespersons for pets' supplies retail stores and pets' caregiver assistant. Table 2 reveals that among the internships for all departments, the cosmetology and tourism departments are already scheduled for internships at the second semester of the fifth year. This is because of the more diverse certificates for cultivation, which requires not only the certificates for cosmetology and store services but also the certificates for language and leader/guides. Moreover, employees believe that training manpower takes time while summer vacation is the peak season for tourism; hence, students can become full-time employees after the internship program.

"Internship for a full academic year" accounts for the second largest proportion, where students experience the influence of industry internship for more period of time by returning to school for class each week while interning at the enterprises in other time. Students will target at employment, which is also known as the internship for enterprises to prepare "entrylevel employees," so that students can experience work in the workplace and fully participate in the educational training and assessment arranged by the company. Competent works include environmental cleaning, customer reception, product sales, account settlement and revenue, product management and technical services. For work with emphasis on technological dimension, students will need longer period of internship period. For example, cosmetics sample preparation assistant, advanced assistant in hair salon industries (dyeing and perming skills), manicurist (advanced nail painting, gel nails techniques), aroma masseur, assistant to pets' artists (assisting pets with beauty styling),

\begin{tabular}{|c|c|c|c|}
\hline $\begin{array}{l}\text { Five-year cosmetology } \\
\text { Education related } \\
\text { department }\end{array}$ & $\begin{array}{l}\text { Internship courses } \\
\text { Summer } \\
\text { internship }\end{array}$ & $\begin{array}{l}\text { Internship during the } \\
\text { semester }\end{array}$ & $\begin{array}{l}\text { Internship for a full academic } \\
\text { year }\end{array}$ \\
\hline Cosmetics Department & & $\mathrm{V}$ & $\mathrm{V}$ \\
\hline $\begin{array}{l}\text { Beauty Styling } \\
\text { Department }\end{array}$ & $\mathrm{v}$ & $\mathrm{v}$ & $\mathrm{v}$ \\
\hline Beauty Care Department & $\mathrm{v}$ & $\mathrm{V}$ & $\mathrm{v}$ \\
\hline Pet Grooming Department & & $\mathrm{v}$ & $\mathrm{v}$ \\
\hline $\begin{array}{l}\text { Beauty Tourism } \\
\text { Department }\end{array}$ & & $\mathrm{v}$ & \\
\hline
\end{tabular}

Internship under five-year cosmetology program

593

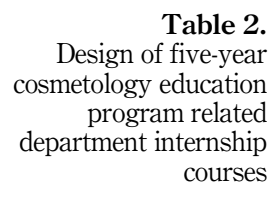

Design of fivecosmetology education program related courses 
HESWBL 11,2

\section{4}

assistant to vet (replacing bandage, cleaning and grooming, hair shaving, nail trimming) and pet training assistant.

Due to the shorter period of workplace internship hours for "summer internships," the learning level of students is more limited to beauty car while department of beauty styling arranges for summer internship with competent work including hair salon assistant for hair washing, wedding gown secretary, assistant for outdoor wedding photo shooting and salespersons. The content of these works is more basic and simpler.

\section{The accumulation of internship experience for students under the five-year cosmetology programs}

The following factors of internship are concluded from the focus group interview: workplace skills, learning attitude, work attitude, interpersonal communication, etiquette standards, internship environment, adaptability, concept cognition and career planning. The different lengths of hours for internship for a full academic year, internship during the semester and summer internship will have subtle influence of different levels in internship experience. Hence the study distributed 118 questionnaire surveys and among which, 47 questionnaires were distributed to students with internship experience, 35 questionnaires were distributed to teachers and 36 questionnaires were distributed to employers, in addition to conducting purposive sampling interview on the internship experience, as shown in Table 3.

The influence of the three different internship courses on the internship experience of students is describe below:

\begin{tabular}{|c|c|c|c|}
\hline Identity & & Internship courses taken & Industry categories accessed \\
\hline Student 1 & $\begin{array}{l}\text { Fifth-year } \\
\text { student }\end{array}$ & $\begin{array}{l}\text { Summer internship, internship } \\
\text { during the semester }\end{array}$ & $\begin{array}{l}\text { Summer internship at hair salon, } \\
\text { internship during the semester at } \\
\text { manicure/pedicure industry }\end{array}$ \\
\hline Student 2 & $\begin{array}{l}\text { Fifth-year } \\
\text { student }\end{array}$ & $\begin{array}{l}\text { Internship during the semester, } \\
\text { internship for a full academic } \\
\text { year }\end{array}$ & $\begin{array}{l}\text { Internship during the semester at } \\
\text { counter sales, internship for a full } \\
\text { academic year at skincare massage }\end{array}$ \\
\hline Student 3 & $\begin{array}{l}\text { Fifth-year } \\
\text { student }\end{array}$ & $\begin{array}{l}\text { Summer internship, internship } \\
\text { during the semester }\end{array}$ & $\begin{array}{l}\text { Summer internship at wedding } \\
\text { photography, internship during the } \\
\text { semester at skincare massage }\end{array}$ \\
\hline Teacher 1 & $\begin{array}{l}18 \text { years of } \\
\text { teaching } \\
\text { seniority }\end{array}$ & $\begin{array}{l}\text { Internship during the semester, } \\
\text { internship for a full academic } \\
\text { year }\end{array}$ & $\begin{array}{l}\text { Hair salon, wedding photographer, } \\
\text { manicure/pedicure, skincare massage, } \\
\text { counter sales }\end{array}$ \\
\hline Teacher 2 & $\begin{array}{l}16 \text { years of } \\
\text { teaching } \\
\text { seniority }\end{array}$ & $\begin{array}{l}\text { Summer internship, internship } \\
\text { during the semester }\end{array}$ & $\begin{array}{l}\text { Cosmetics biotech company, hair salon, } \\
\text { counter sales }\end{array}$ \\
\hline Teacher 3 & $\begin{array}{l}13 \text { years of } \\
\text { teaching } \\
\text { seniority }\end{array}$ & $\begin{array}{l}\text { Internship during the semester, } \\
\text { internship for a full academic } \\
\text { year }\end{array}$ & $\begin{array}{l}\text { Hair salon, wedding photography, } \\
\text { manicure/pedicure, skincare massage }\end{array}$ \\
\hline $\begin{array}{l}\text { Employer } \\
1\end{array}$ & $\begin{array}{l}15 \text { years of } \\
\text { industry } \\
\text { experience }\end{array}$ & $\begin{array}{l}\text { Summer internship, internship } \\
\text { during the semester, internship } \\
\text { for a full academic year }\end{array}$ & Counter sales \\
\hline $\begin{array}{l}\text { Employer } \\
2\end{array}$ & $\begin{array}{l}13 \text { years of } \\
\text { industry } \\
\text { experience }\end{array}$ & $\begin{array}{l}\text { Summer internship, internship } \\
\text { during the semester, internship } \\
\text { for a full academic year }\end{array}$ & Wedding photography \\
\hline $\begin{array}{l}\text { Employer } \\
3\end{array}$ & $\begin{array}{l}11 \text { years of } \\
\text { industry } \\
\text { experience }\end{array}$ & $\begin{array}{l}\text { Summer internship, internship } \\
\text { during the semester, internship } \\
\text { for a full academic year }\end{array}$ & Hair salon \\
\hline
\end{tabular}

Table 3.

Interview respondents 


\subsection{Students' internship experience accumulated from summer work}

The results concluded from the questionnaire as sorted in Figure 2, whereas the cumulated leaning experience from summer internship reaches $100 \%$ in believing that the most important is the cultivation of "work attitude," followed by "interpersonal communication" (94.4\% while "adaptability" and "learning attitude" also account for $70 \%$ ).

Since students just enter the workplace from campus and can have relatively weaker skills acquired from the workplace under short period of time, some teachers suggest:

Teacher 2: "Most students can learn the enthusiastic attitude for work from full-time employees."

Observing the employees attending customers at workplace will help the students understand the work attitude to be equipped by the relevant job holders and thereby improve their learning and requirement. For example, student 3 indicated: "Seeing employees assisting customers selecting the wedding gown, and regardless of the pieces of clothing customer try on, they continue until customers are satisfied."

Students learn from full-time employees for their exhibition of diligent and enthusiastic work attitude at their position through short-term summer internship. Students will first accumulate experience in work attitude, and to help upgrade the design of summer internship, the schools may offer courses related to professional ethics.

The beauty-related industries are one section of service industries and enhance interaction with interpersonal exchange through the process of serving. Interpersonal communication will aid carrying out work and has the advantage of improving sales. For example, student 3 indicated: "We need to learn to talk to different people by topic in order to help customers elect the suitable style of wedding gown and to sell some products."

Nonetheless, the beauty-related industries require strength and technology to provide services to customers, and it is inevitable for employees to face with some emotional stress. Some employers indicate:

Employer 3: The salon industries require long-term standing, non-regular meal hours or could meet customers who are difficulty to cope with. . .

To help students resolve the adaptability that occurred during the summer internship, they will require more influence of emotional management.

Since the summer internship only lasts for two months but the students must acquire the most fundamental and simple work content, hence the interns often regard themselves as learners in the work field and in terms of attitude. The students and employers indicate:

Student 1: There is a supervisor from the store who was specially assigned to teach me the hair washing skills. Since the time to learn is limited, so I need to learn more with more enthusiasm.

Employer 3: Interns must pass the assessment in 2 weeks and so students must learn with enthusiasm.

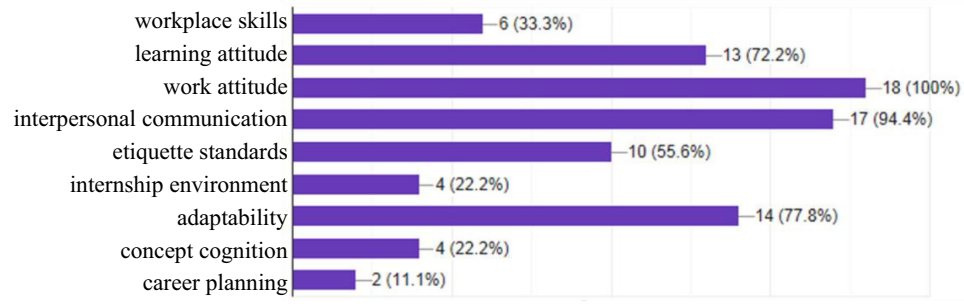

Figure 2.

Experience accumulated from summer internship 
HESWBL 11,2

\section{6}

Figure 3.

Experience accumulated from internship during the semester
4.2 Students' internship experience accumulated from work during the semester

The questionnaire results are compiled and sorted in Figure 3. The results indicate the most learning experience accumulated from internship during the semester, among which "interpersonal communication" accounts for $81.2 \%$, "work attitude" accounts for $78.3 \%$ and "workplace skills" account for $76.8 \%$. In particular, interpersonal communication/skill accounts for the majority mainly because the interns have developed fundamental work skills from half year of internship and interns will work and endeavor to operate "commercialized" interpersonal exchange and interaction in order to meet the requirement of improving work performance. Students and teachers indicate:

Student 1: Even if I am just an intern, I still have stress for sales and need to possibly expand the relation between the customers and me.

Teacher 1: Most interns wish to accumulate their work performance through massive international relationship.

To benefit students with learning effect from internship during the semester, students will need to increase their courses or activities related to interpersonal communication and marketing management.

Students not only learn corporate service culture to customers through the experience of internship during the semester for half year but also develop proactive, positive and responsible work attitude and performance by learning. The students indicate:

Student 2: Apart from owning excellent oral skills, the company also promotes the educational training slogan for "touching services" with enthusiasm, namely to provide services to customers through friendly and enthusiastic approach with respect shown for work.

Establishing good work attitude in internship during the semester will improve students' respect for work in professional ethics so that students can accumulate the fundamental skills from work experience and stay competent for the entry-level work and serve the role of intermediate-level assistant. The employers indicate:

Employer 2: Students develop workplace skills and practice capacity. These skills are the work competency and performance of attitude which the work force should be equipped.

Employer 3: Students having internship at the hair salon industry for half year can mostly become intermediate-level assistant.

\subsection{Internship experience accumulated by students for a full academic year}

The questionnaire results are compiled and sorted in Figure 4. The results indicate the most learning experience accumulated from internship for a full academic year, among which "workplace skills" account for 96.8\%, "work attitude" and "interpersonal relation" account for $77.4 \%$, respectively. In particular, "workplace skills" account for the majority of

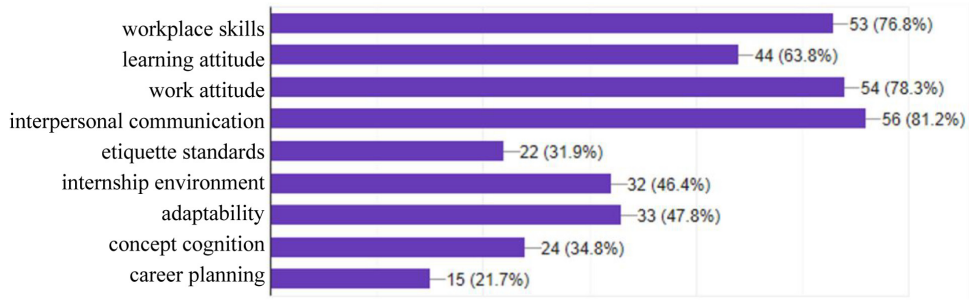


experience mainly because the objectives of internship for a full academic year are employment-oriented, where both students and employers believe the interns for a full academic year are similar to full-time employees, who indicate:

Student 2: The store manager told me that I was no different from the other full-time employees and I can now directly provide skincare and massage to customers.

Employer 1: The interns of a full academic year are comparable to full-time employees because the interns can cover all different affairs in the store.

The interview reveals the enlightenment for course planning: it is suggested to integrate the industry collaboration teaching approach with technical courses prior to the internship for a full academic year so that the experts and professors of the industries can instruct new knowledge and skills to help students make progress in the internship courses for the full academic year.

Interns for a full academic year are already in the role of full-time employees and must devote to work and manage the relation with customers in order to improve the sales. Hence, work attitude and interpersonal communication are just as important. Respondents indicate:

Teacher 1: Interns are like the employees of the company, who need to show enthusiasm for work and must manage the interpersonal relation with customers.

Teacher 3: Students need to experience and simulate the actual working condition when interning on campus, practicing interaction with customers and this will help with off-campus internship.

Employer 1: In the beauty fashion industries, consumers are the investors and we need to cultivate the art of getting along with people.

Since internship for a full academic year requires long-term working in the industry, students accumulate work attitude and the experience of interpersonal communication from the internship process. To strengthen the student's internship effect, the enlightenment drawn from the interview suggests that schools should offer professional ethics and interpersonal communication, on-campus internship, career planning and activities for presenting internship outcome in terms of internship courses for a full academic year.

\section{Conclusion}

The internship of five-year cosmetology technical and vocational education program can be reflected for the design of internship courses. First, the most experiences accumulated from summer internships are: "work attitude," "interpersonal communication," "adaptability" and "learning attitude." The initial step is to understand the content of course design from the school by offering professional ethics, interpersonal communication, emotional management and holding workplace experience activities, which will help students make progress in summer internship. Secondly, the most experience accumulated in internship during the semester is in the order of "interpersonal communication," "work attitude" and

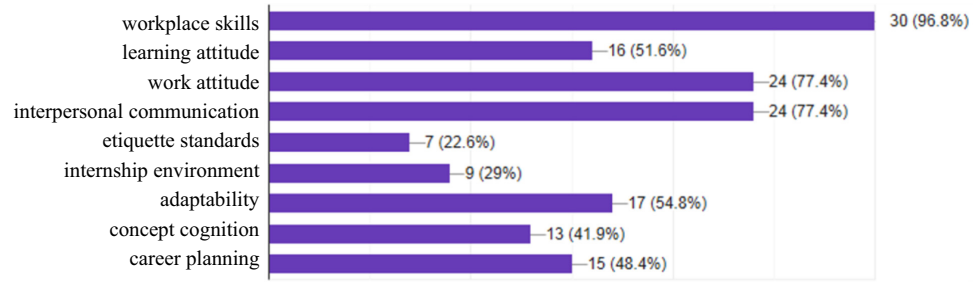

Internship under five-year cosmetology program

597

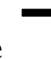


HESWBL 11,2

\section{8}

"workplace skills." The initial step is to understand the design of internship courses during the semester by offering interpersonal communication, marketing management and professional ethics, as well as activities presenting the internship outcome, thereby improving the effect of internship courses during the semester. The most experience accumulated from internship courses for a full academic year is in the order of: "Workplace skills," "work attitude" and "interpersonal communication." Internship for a full academic year is the course for employment orientation, which integrates the on-campus technical courses before internship into industry collaboration teaching approach, so that industry experts can introduce new industry know-how into campus. Moreover, the courses on oncampus internship, professional ethics, interpersonal communication and career planning, as well as holding activities presenting internship outcome will help students validate their future career orientation. Regardless of summer internship, internship during the semester or internship for a full academic year, there is no absolutely correct answer to which internship course is the most suitable internship course. However, the main intent is to allow students to realize and reflect from internship experience about themselves and the workplace work. "Learning from experience" has profound meaning on the off-campus internship courses for five-year cosmetology technical and vocational education programs.

\section{References}

Attick, D. (2007), "Television, experience, and knowledge: a Deweyan critique of TV in the lives of American youth", Journal of College and Character, Vol. 8 No. 4, pp. 1-10.

Billett, S. (2001a), "Co-participation: affordance and engagement at work", New Directions for Adult and Continuing Education, Vol. 92, pp. 63-72.

Billett, S. (2001b), "Learning through work: workplace affordances and individual engagement", Journal of Workplace Learning, Vol. 13 No. 5, pp. 209-214.

Billett, S., Newton, J. and Ockerby, C.M. (2010), "Socio-personal premises for' selecting and securing an occupation as vocation", Studies in the Education of Adults, Vol. 42 No. 1, pp. 47-62.

Chang, J.C. and Wong, C. (2016), "The current situation and empirical analysis of off-campus internship of technological colleges and universities in Taiwan", Journal of Technlogical and Vocational Education, Vol. 7 No. 1, pp. 23-47.

Dewey, J. (1944), Democracy and Education, The Free Press, New York.

Gordon, M. and English, A.R. (2016), “John Dewey's democracy and education in an era of globalization", Educational Philosophy and Theory, Vol. 48 No. 10, pp. 977-980.

Hu, C.-Y. (2013), "A study on the establishment and effects of quality assurance mechanism of student learning outcomes for Junior College", $\mathrm{PhD}$ thesis, Institute of Educational Administration and Evaluation of University of Taipei, Taipei City.

104 Human Resource Bank (2018), “Job opening query”, available at: http://www.104.com.tw/.

1111 Human Resource Bank (2018), "Job opening query”, available at: http://www.1111.com.tw/.

King, K. (1993), "Technical and vocational education and training in an international context", The Vocational Aspect of Education, Vol. 45 No. 3, pp. 201-216.

Lin, S.J. (2007), Exploring Experience and Education-An Interpretation of Dewey's Educational Philosophy, Lucky Bookstore, Taipei City.

Lin, Z.-Y. (2012), “On John Deweys continuity of experience”, Master's thesis, Huafan University Department of Philosophy, New Taipei City.

Ministry of Economic Affairs, R.O.C (2018), "Cosmetic industry", Industrial Economic Statistics Newsletter, Vol. 305, p. 1.

Ministry of Education (2014), Junior College Law, Ministry of Education, Taipei City. 
Ministry of Education (2016), "12-year compulsory education five-year Junior College recruiting website - a guide to higher education and introduction of five-year Junior Colleges", Ministry of Education, Taipei City.

Ministry of Education (2017), "12-year compulsory education five-year Junior College recruiting website - nationwide five-year Junior College information”, available at: http://me.moe.edu.tw/ junior/search/list_dep2.php?clf $=51$.

Moodie, G. (2002), "Identifying vocational education and training", Journal of Vocational Education and Training, Vol. 54 No. 2, pp. 249-266.

Wu, M.-K. (2009), "The insights of John Dewey's empirical philosophy for curriculum and teaching”, Journal of University of Taipei -Education, Vol. 40 No. 1, pp. 35-54.

\section{Corresponding author}

Yeh Ju-Hsuan can be contacted at: aliceyeh@ctcn.edu.tw
Internship under five-year cosmetology

program

599

For instructions on how to order reprints of this article, please visit our website:

www.emeraldgrouppublishing.com/licensing/reprints.htm

Or contact us for further details: permissions@emeraldinsight.com 